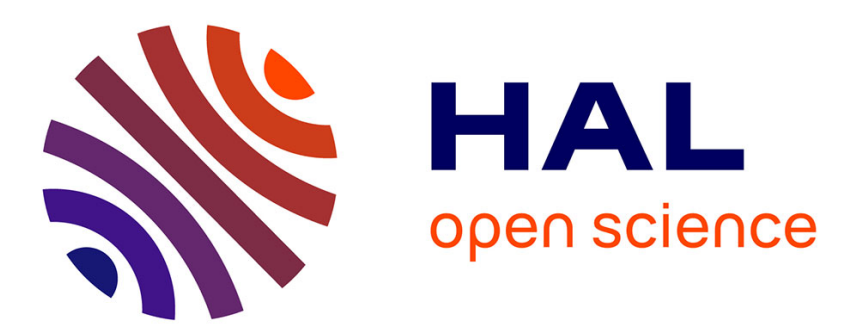

\title{
Green approaches for the synthesis of nucleotides, their conjugates and analogues
}

\author{
Lucie Appy, Anaïs Depaix, Xavier Bantreil, Frédéric Lamaty, Suzanne \\ Peyrottes, Béatrice Roy
}

\section{- To cite this version:}

Lucie Appy, Anaïs Depaix, Xavier Bantreil, Frédéric Lamaty, Suzanne Peyrottes, et al.. Green approaches for the synthesis of nucleotides, their conjugates and analogues. Phosphorus, Sulfur, and Silicon and the Related Elements, 2020, 195, pp.930 - 931. 10.1080/10426507.2020.1804164 . hal03407438

\section{HAL Id: hal-03407438 \\ https://hal.science/hal-03407438}

Submitted on 28 Oct 2021

HAL is a multi-disciplinary open access archive for the deposit and dissemination of scientific research documents, whether they are published or not. The documents may come from teaching and research institutions in France or abroad, or from public or private research centers.
L'archive ouverte pluridisciplinaire HAL, est destinée au dépôt et à la diffusion de documents scientifiques de niveau recherche, publiés ou non, émanant des établissements d'enseignement et de recherche français ou étrangers, des laboratoires publics ou privés. 


\title{
Green approaches for the synthesis of nucleotides, their conjugates and analogues
}

\author{
Lucie Appy, ${ }^{1}$ Anaïs Depaix, ${ }^{1}$ Xavier Bantreil, ${ }^{2}$ Frédéric Lamaty, ${ }^{2}$ Suzanne Peyrottes, ${ }^{1}$ \\ Béatrice Roy ${ }^{1}$ \\ ${ }^{1}$ Nucleosides \& Phosphorylated Effectors, IBMM, Univ Montpellier CNRS, ENSCM, Montpellier, France \\ ${ }^{2}$ Green Chemistry and Enabling Technologies, IBMM, Univ Montpellier CNRS, ENSCM, Montpellier, France \\ beatrice.roy@umontpellier.fr
}

\begin{abstract}
We have developed original one-pot and protecting group-free approaches, which are also user-friendly and reliable, to synthesize nucleotides and derivates starting from nucleoside 5 '-monophosphates. Both methods present convenient set-up, i.e. non-dry solvents and reagents, substrates in their sodium or acid form, and commercially available and cheap phosphorus reagents as sodium and potassium salts.
\end{abstract}

\section{GRAPHICAL ABSTRACT}

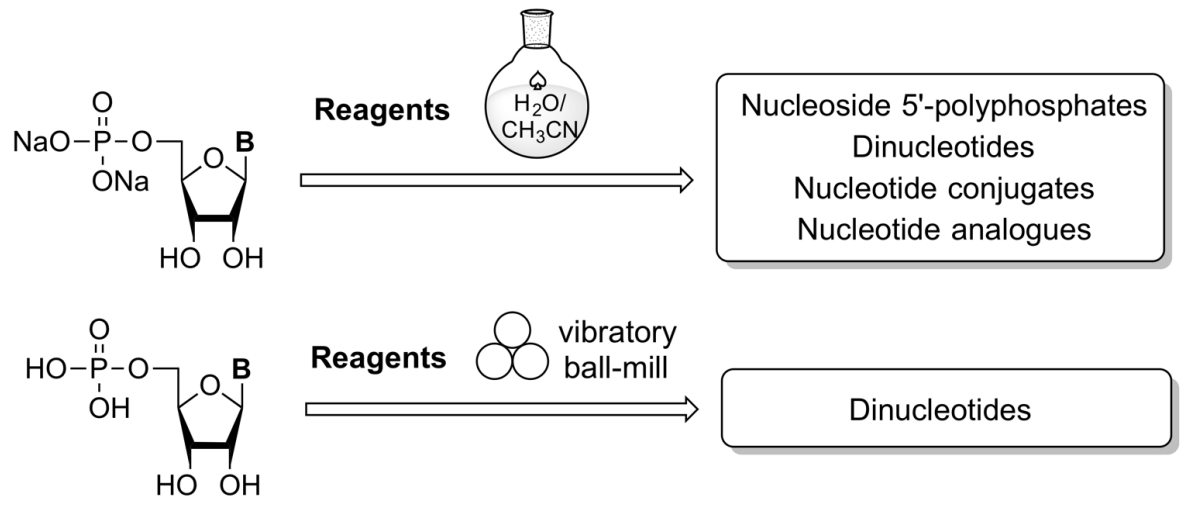

\section{KEYWORDS}

organophosphorus chemistry; nucleotides; dinucleotides; water chemistry; mechanochemistry. 


\section{INTRODUCTION}

Nucleotides and their derivatives are essential to human biological systems. Numerous methods have been developed to prepare these compounds and their structural analogues. ${ }^{1-4}$ Their scope range from mechanistic probes to versatile chemical tools for assay development and biomedical applications. ${ }^{1}$ Most of these synthetic approaches present important drawbacks, such as the use of non-volatile and harmful solvents (DMF, pyridine), preparation of substrates or phosphorus reagents in their alkylammonium forms due to solubility issues, anhydrous conditions, and fastidious purifications.

\section{RESULTS AND DISCUSSION}

We proposed one-pot and protecting group-free approaches, which are user-friendly and reliable, for the preparation of nucleotides. Starting materials are nucleoside 5'-monophosphates (NMPs) which are readily converted into a common intermediate, i.e. the nucleoside 5'phosphorimidazolide. The use of non-dry solvents and reagents, substrates in their sodium or acid form, and commercially available and cheap phosphorus reagents as sodium and potassium salts shall allow an easy implementation of these procedures.

In the first strategy, nucleoside 5'-monophosphates were activated into the corresponding phosphorimidazolide intermediates (NMP-Im) using 2-chloro-1,3-dimethylimidazolinium hexafluorophosphate (DMP) and imidazole in a mixture of acetonitrile and water (Scheme 1). ${ }^{5-6}$ The resulting intermediates were then treated with sodium phosphate or sodium pyrophosphate to afford the corresponding nucleoside 5'-diphosphates and 5'-triphosphates, respectively. The conversion rates ranged from 35 to $49 \%$, and the compounds were isolated in $22-40 \%$ yields. We then extended this approach to the synthesis of a nucleotide conjugate (i.e., CDP-choline), and various analogues modified either on the glycosyl moiety (i.e., AZTDP and AZTTP) or on the phosphate moiety such as $\beta, \gamma$-methylene-uridine 5'-triphosphate.

Moreover, we took advantage of the formation of byproducts during the activation step and corresponding to the dimers to isolate these compounds. In this respect, several NMPs (UMP, 
CMP, and AMP) were reacted with DMP and imidazole until the total disappearance of the ${ }^{31} \mathrm{P}$ NMR signal of the activated NMPs. The conversion rates for dimers ranged from 31 to $70 \%$.

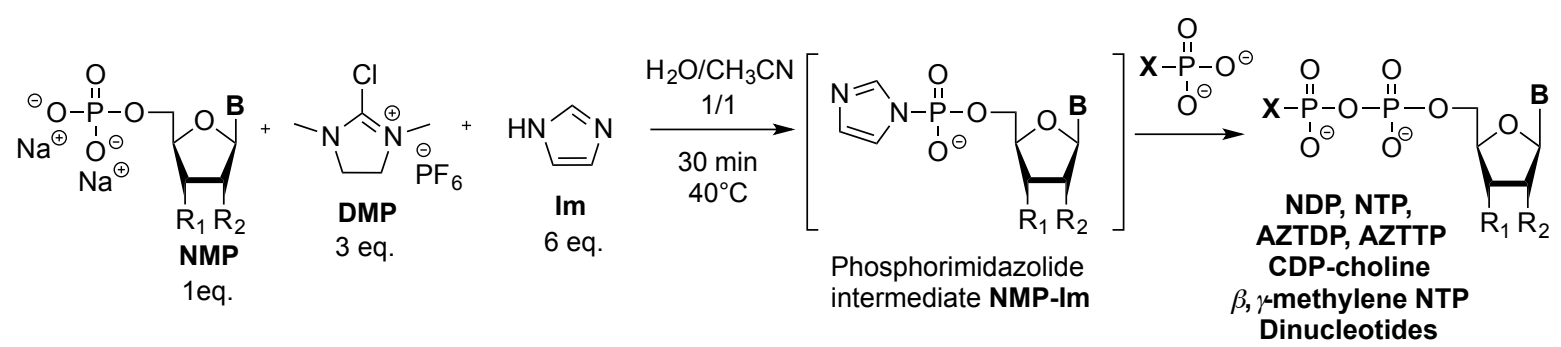

Scheme 1 Synthetic route to nucleotides and derivatives in aqueous media $(\mathbf{B}=$ Uracil, Cytosine, Adenine $) .^{5-6}$

In the second strategy, we envisaged the use of mechanochemistry, an emerging technique that enables solid/solid reactions through mechanical grinding under solventless or solvent-free conditions, ${ }^{7-8}$ and that was recognized in 2019 by IUPAC as a chemical innovation that will change the world. ${ }^{9}$ Under ball-milling conditions, nucleoside 5' -monophosphates in their acid form were quantitatively converted into their phosphorimidazolide derivatives using the eco-friendly $N, N^{\prime}-$ carbonyldiimidazole (CDI) (Scheme 2). ${ }^{10}$ Thus, the addition of a nucleoside 5'-mono, di or triphosphate led to the formation of the corresponding unprotected dinucleotides in satisfactory yields (Scheme 2). Benefits of this one-pot method include short reaction time, high conversion rates $\left(75-100 \%\right.$, except for $\left.\mathrm{Gp}_{2} \mathrm{U}\right)$ and easy set-up and purification.

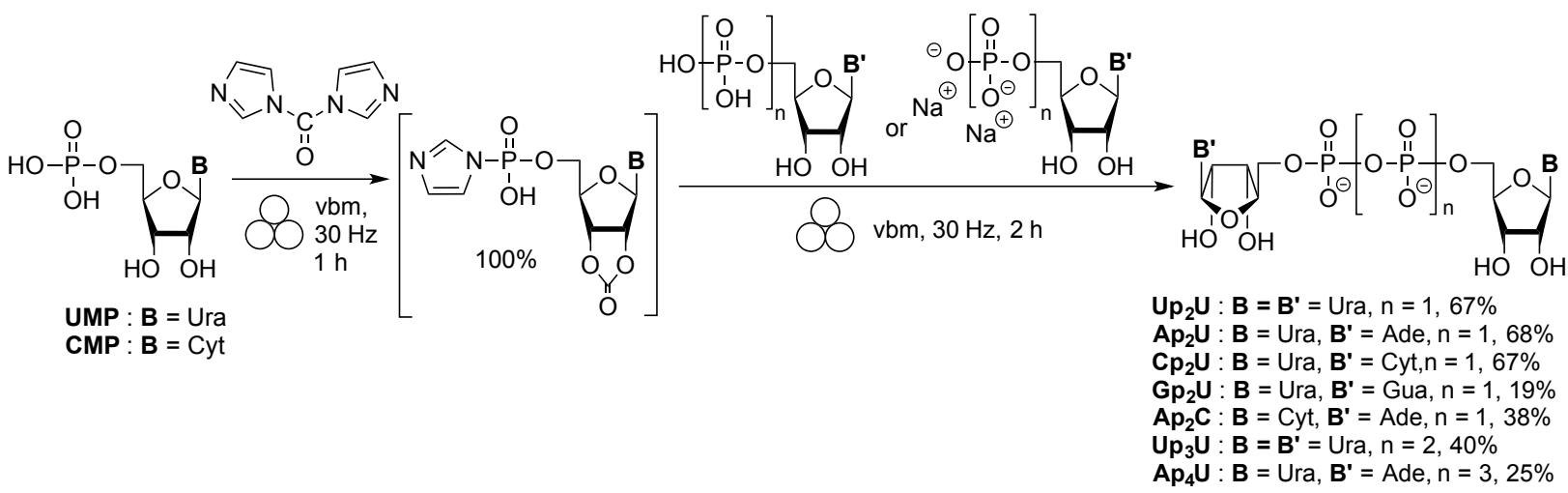

Scheme 2 Synthetic route to $5^{\prime}, 5^{\prime}$-dinucleotides via mechanochemistry. ${ }^{10}$ 


\section{CONCLUSIONS}

This work offers new opportunities for the synthesis of nucleotide conjugates and their analogues, combining the phosphorimidazolide approach and milling conditions. These last being essential intermediates for pyrophosphate bond formation, our studies open the way to environmentally friendly practices to access a wide range of nucleotide derivatives.

\section{REFERENCES}

1. Roy, B.; Depaix, A.; Périgaud, C.; Peyrottes, S. Recent Trends in Nucleotide Synthesis. Chem. Rev. 2016, 116, 7854-7897.

2. D. R. W. Hodgson. Physicochemical Aspects of Aqueous and Nonaqueous Approaches to the Preparation of Nucleosides, Nucleotides and Phosphate Ester Mimics. Advances in Physical Organic Chemistry (Eds.: I. H. Williams, N. H. Williams), Oxford: Academic Press, 2017, pp. 187-219.

3. $\mathrm{Xu}, \mathrm{Z}$. A Review on the Chemical Synthesis of Pyrophosphate Bonds in Bioactive Nucleoside Diphosphate Analogs. Biorg. Med. Chem Lett., 2015, 25, 3777-3783.

4. Jessen, H. J.; Ahmed, N.; Hofer, A. Phosphate Esters and Anhydrides - Recent Strategies Targeting Nature's Favoured Modifications. Org. Biomol. Chem, 2014, 12, 3526-3530.

5. Depaix, A.; Peyrottes, S., Roy, B.; One-Pot Synthesis of Nucleotides and Conjugates in Aqueous Medium. Eur. J. Org. Chem. 2017, 241-245.

6. Depaix, A. ; Peyrottes, S. ; Roy, B. Water-Medium Synthesis of Nucleoside 5'-Polyphosphates. Curr. Protoc. Nucleic Acid Chem. 2017, 69, 13.16.1-13.16.11.

7. Friščić, T. ; Mottillo, C. ; Titi, H.M. Mechanochemistry for Synthesis. Angew. Chem. Int. Ed. Engl. 2019, 59, 1018-1029.

8. Eguaogie, O. ; Vyle, J. S. ; Conlon, P. F. ; Gilea, M. A. ; Liang, Y. Mechanochemistry of nucleosides, nucleotides and related materials. Beilstein J. Org. Chem. 2018, 14, 955-970.

9. Gomollon-Bel, F. Ten Chemical Innovations that will Change our World. Chem. Int. 2019, 41, $12-17$.

10. Appy, L.; Depaix, A.; Bantreil, X.; Lamaty, F.; Peyrottes, S., Roy, B.; Straightforward Ball-Milling Access to Dinucleoside 5',5'-Polyphosphates via Phosphorimidazolide Intermediates. Chem. Eur. J. 2019, 9, 241-245.

Received xx yyyy 2020; accepted xx yyyy 2020, International Conference on Phosphorus Boron and Silicon 2019 Insert acknowledgements and thanks 